\title{
Research Value of the "Little Magazine"
}

Some research resources which may not always be fully appreciated as seen by an assistant professor at Ohio State University.

I THE PAST few years, scholars and critics who have interested themselves in problems of contemporary literature have been awakening to the great problem of finding adequate materials with which to work. They do not have the advantages which help the scholar of Elizabethan drama, for example-advantages which are the end product of years of painstaking research and careful accumulation and ordering of scholarly evidence. For the student of twentieth-century literature, adequate and accurate criticism, interpretation, and discussion are far more difficult than they are in matters which have been thoroughly explored and which are at least relatively settled. Indeed, this is one of the most effective arguments against the undertaking of research in contemporary letters: though there is a great sufficiency of "documents," these documents have no more order than their mere existence affords; they are neither adequately cataloged nor accurately classified; the wilderness of contemporary letters remains uncharted.

Criticism of modern literature has shown the sad effects of these conditions. Much of this criticism is impressionistic and tentative and is the result more of immediate intuition than of serious reflection. The abundance of materials has often proved more embarrassing than helpful. Much modern criticism of literature in the making is handicapped by two unfortunate circumstances: (I) the critic is constantly making over his opinion of a contemporary literary artist and his judgment is, therefore, seldom to be considered mature, since it is always subject to change of a sort trivial or profound. On Monday he may regard Mr. X as a brilliant interpreter of the mal de siècle; on Tuesday he has so altered his opinion that $\mathrm{X}$ becomes a poet of the avantgarde, an experimentalist, and therefore an artist whose merit is a huge question mark; (2) too often critics, embarrassed as they are by long publisher's lists and often by date deadlines for their reviews or essays, rely upon the publication in book form of any writer's work as the final and only statement. Much recent literary history suffers from this latter fault. With little if any awareness of a modern writer's esthetic biography, the critic seizes upon an author's books as the point of final reference, the basis of any and all judgment regarding his merit, his integrity, and his place in literary history. This is perhaps no more than fair and just. Once a writer submits to his publisher's good graces, he may be said to have given up any doubts about his own merit; and the critic is perhaps justified in assuming that publication in book form is an admission, on an author's part, that his work has reached a form of publishable maturity. But such an assumption, though valid in a majority of cases, is guilty of a fundamental error of omission. It neglects, altogether, a factor in all literary history which 
is extremely important-the problem of literary genesis-the means by which a literary artist grows and by which his work matures.

In view of both of these weaknesses in modern criticism, I should like to suggest that critical estimates of a great majority of twentieth-century poets and fictionalists will have to undergo a thorough revision in the years immediately ahead of us. This is, fortunately, a good time for this kind of reappraisal. We now see the second, third, and fourth decades of our century in some definite perspective-a perspective which is the product, not so much of chronology, as of major social, political, and economic events. We shall no doubt identify the years $1919-39$ as a distinct and important "period" in the literary history of our century. We shall, in the future, be able to study those twenty years as a unit of time during which important events in the history of ideas paralleled those in other spheres of human endeavor. How go about this business of re-evaluation? Will the perspective which another postwar era will inevitably afford us be sufficient unto the needs thereof?

\section{Must Cover More Than Books}

The answer to these questions ought to be obvious enough. Literary history is more than a study of books published; it involves also a careful study and survey of the genesis of literary ideas and of the slow progress from tentative and halting adolescence to the final maturity of a writer's style and content. In order to make any reasonable judgment concerning the writers of our century, we shall have to study their work from beginning to end -and this task requires going to the "little magazines" in which so many of our most important writers made their first selfconscious and embarrassed bows before their reading public.
Scholarship and criticism will become more and more indebted to the little magazine for whatever they may need in the matter of revising estimates of twentieth-century literature. This is an important fact and one whose importance will grow larger and larger as little magazines become increasingly available to the scholar and the critic. But the criticism of writers living or recently dead is so much in its beginning phases that few critics know much about these little magazines. If they are aware of one or two of them, they fail to see the importance of a score of others. If they have read the few essays on little magazines which have appeared recently, they are still all but unaware of the highly significant part which these magazines have played in twentieth-century literature. What is needed more than anything else is a definition of the little magazine-a guide by which a scholar or a critic may identify the little magazine, and thus classify it.

\section{For Publishing Work of Merit}

A little magazine is one which has been established primarily for the purpose of publishing work of some artistic merit. This work is usually unacceptable to the commercial periodical for one or another of the following reasons: (I) its author is completely unknown and is therefore not a good "risk," for his work will not increase the circulation of the magazine; (2) the work may be written in a form unconventional and not immediately intelligible to the commercial magazine's public; (3) it may also violate one or several of that public's notions of polite moral, social, or esthetic behavior, and may, therefore, be frowned upon or forced to retreat from the formidable battlefield of popular preference. In view of these objections to new and often startling work by new and untried writers, the little magazine has ap- 
peared in twentieth-century literary history as the answer to a definite need. Its editors often proclaim, with considerable seriousness and with great fervor, that the little magazine is vital to the health and growth of literature. It is needed to prevent absolute stagnation in the history of modern letters. But these editors are almost always amateurs and, like most amateurs, they possess enthusiasm and energy but have little, if any, knowledge of the great difficulties encountered in keeping a magazine alive. Suppose we try to draw a "composite portrait" of the little magazine editor or contributor. There is an abundance of material to draw from for this experiment in characterization. We might look back upon the careers of Ezra Pound, William Carlos Williams, Eugene Jolas, Edward J. Walsh, and Samuel Putnam. These men differ widely in their personal tastes and beliefs, but their activities in editing and contributing to little magazines have enough in common to give us some opportunity for generalizing about them. An editor of a little magazine, or a contributor to one (they are more often than not one and the same person), usually begins his carer in a state of discontentwhether with the constraints of his world or with the irritating negligence of publishers (their exasperating indifference to work of merit) -at any rate, with something he considers unjust, boring, or even ridiculous. $\mathrm{He}$ views the world of publishers and popularizers with contempt, sometimes with despair. If he wishes to begin his career as a writer and finds that the only openings are those in the commercial magazines, he is faced with the prospect of abandoning certain unorthodox esthetic or moral beliefs. Often he is rebellious against the doctrines of popular taste and sincerely believes that our attitudes toward literature need to be reformed, or at least made more liberal. More than that, he generally insists that publication should not depend upon the whimsy of conventional tastes and choices.

\section{Spirit of Revolt}

Certainly one of the great values of the little magazine, for scholars and critics who are anxious to know more about the cultural history of their century, lies in its spirit of conscientious revolt against the guardians of public taste. Freedom from such control often leads to confusion. We can have little hope, therefore, for a simple clarification of our age from the little magazine, especially since editors are many and quarrels frequent. There is a tangled but delightful sense of contradiction in the total picture. One gets the impression that many writers, neither having had nor desiring the formal schooling which a calmer age grants somewhat pompously, were at the business of making up their minds and liking it very much. The great seriousness with which some of the little magazines pronounce the dawn of a new cultural synthesis is forever being disturbed by an annoying spirit of dada which animates certain others.

Because of the urgent conviction that he has something to say but is prevented by commercial publishers from saying it in his own way, our little magazine editor must search for some means of publication outside the limits established by commercial periodicals. $\mathrm{He}$ finds, or is misled into believing, that the resources for beginning a magazine are availablethough he often does not see clearly beyond the publication of the first issue. Generally, he is deeply absorbed in the importance of what he has to say; but his interest in establishing and illustrating his own esthetic beliefs leads him to neglect such matters as might insure either a wide distribution or a reasonably long life for his magazine. 
We ought to have guessed by this time that the wisdom of little magazine editors is generally confined to matters of the art of writing itself. Only occasionally do they show wisdom, or even competence, in practical matters. In fact, many of them pride themselves on their lack of such competence. They are genuine amateurs in the profession of publishing. Their amateur status is an indispensable accompaniment and a rather unfortunate result of their esthetic integrity-unfortunate because these magazines are the despair of both the bibliographer and the librarian. To say the very least, the editorial habits of little magazine personnel are eccentric. Its editors usually live an issue-to-issue existence; their concern is primarily for the present issue, not for any intelligible continuity of sequence or contents which might make the scholar's task the easier. The little magazines often pursue a perilous career, steering their courses uncertainly and erratically. Apparently the only certainty about them is the probability of early collapse.

Morton Dauwen Zabel, reviewing the then current literary magazines in the March 1933 issue of Poetry, remarks that "it becomes apparent that the multiplication of these periodicals atones for their individual impermanence; that despite their varying shades of policy and opinion, their functions are ultimately identical and their activities continuous." This is to say that though many die, many more are being born, and that this will continue to be true as long as there are young writers with courage, disregard for the requirements of the "dignified press," a few dollars in their pockets (or an interested friend or two who can pay the bills), and, finally, an abundance of sheer nerve. What makes the magazines "little" also insures their appearing everywhere and at any timeand disappearing without apparent cause.

\section{Proving Ground for $W$ riters}

But all of this might be no more than an interesting little side excursion into the history of literature were it not true, also, that the little magazines of the twentieth century are the proving ground for a great majority of our writers. It is in these magazines that the professor, the scholar, and the critic will find source materials for all of their studies of modern literature. Charles Allen, of Purdue University, in a study he has made for The Sewanee Review, estimates that about 80 per cent of our most important modern critics, poets, and fictionalists first appeared in little magazines. We find Ernest Hemingway's first work in The Double-Dealer, a New Orleans little magazine of the twenties; William Falkner's first appearance in the same magazine; T. S. Eliot's first appearances in Others and Poetry; and John Malcolm Brinnin's first showing in a Detroit magazine, Prelude, of which he was also an editor. Hart Crane's first published poem appeared in Bruno's Bohemian, one of several magazines put out by Giordano Bruno in the Greenwich Village of the second decade; most of his "juvenilia" appeared in Joseph Kling's Village magazine, The Pagan.

In these facts-and the list of such appearances seems endless-resides the final importance of the little magazine for the scholar and the research worker. Though we must always work in the interest of establishing critical standards by which we can select the best of any writer's work and ultimately prove the justness and validity of our selection, the task of the scholar goes beyond that. He ought to make his study of any writer inclusive. He cannot afford to dismiss evidence before he has seen it. For this reason, he will have to go to the little magazines for a study of a writer's early work if he wishes to present that 
writer's total product as a unit of literary biography or to make from it a wise selection of what might endure.

Take, for example, the problem of forming some estimate of the poetry of Hart Crane. Crane is a conspicuous product of little magazine policies. His writing went into the pages of little magazines for years before he was accepted as a representative modern poet and his poems were published in book form by a commercial publisher. Some of these poems are not republished at all in the version of his Collected Poems which appeared in 1933 under the Liveright imprint. It is true that the poemsmost of them early efforts-that are not in the collected edition are absent for a good reason. They are badly writtenhalting, ineffective efforts-scarcely recognizable as the product of the same pen which wrote The Bridge. But for the scholar, these poems ought to be studied; and the only place where they can be found is in the little magazines themselves. No critic of Hart Crane's work can consider that work satisfactorily examined until he has seen those issues of The Pagan in which so many of the "juvenilia" were published. He may not consider any of these poems as worthy of grouping with The Bridge (indeed, I should regard him as a poor enough critic if he did). But he will be guilty of violating a cardinal principle of research if he does not examine each one of them.

\section{Writings in Original Form}

Another fact which makes the little magazines important to the scholar: it is in them that he will find important writings in their original state. Magazine publication often bears the same relationship to book publication as does manuscript itself. The writer, contemplating the appearance of his work in book form, will want to study that work as it has appeared in little magazines and, perhaps, to revise it. The scholar will often, therefore, have two or three versions of a single work, and he can study the development of a writer's craft by considering each in its turn.

Finally, the little magazines are of fundamental importance to the student and professor of twentieth-century literature because they are a mine of information about the intellectual habits and predispositions of our day. For the editorials, the manifestoes, the pronunciamentos, the controversies, are all there. Very few little magazines fail to give the student an opportunity for examining the raison d'être of modern writing. Most of them argue and defend their contributions to literature at great length. It is an interesting experience-that of following the editorial careers of modern writers-as their work proceeds from issue to issue, from magazine to magazine, accompanied by the editorial rhetoric and invective of their sponsors. Not only do we get the writing of our century in these magazines; we find out what the writers themselves think of it. Our century has been characterized by an elaborate and insistent self-appraisal. Few are the poets who are not also critics-of their own work and of that of their contemporaries. Much of this self-appraisal is to be found in no other place than in the little magazines. It has never been published elsewhere. We should be poor judges indeed who did not allow the defendant a chance to speak before we either consign him to oblivion or suffer him to remain in the histories of our literature.

\section{Source Materials of Scholarship}

The little magazines are of inestimable value for the scholar and the critic because in their pages we find the source materials of the only scholarship worthy of the name. There is no doubt of this fact, and it will be recognized with increasing readiness in the years to come. How can libraries and 
university departments of literature prepare themselves for the studies of twentiethcentury literature which will inevitably appear in the future? It is my opinion that no university library can consider itself adequately equipped for research in modern literature unless it has complete files of at least fifteen important little magazines. Without them, the graduate student will have to be satisfied with only a partial view of his subject or he will have to travel to one or another of the libraries which have these magazines. The following may be considered as the fifteen most important little magazines of our century: The Little Review, Transition, Poetry, The Seven Arts, The Double-Dealer, Broom, Secession, Others, The Masses, The Fugitive, The Partisan Review, This Quarter, The Reviewer, Story, and The Midland. It is hard to set a limit to such a list; I am sure that there are several others with just claims for inclusion.

For the rest, a university library may follow one of two courses: (I) it may, if it has a large surplus of funds, attempt to collect complete files of a much larger representation-let us say a hundred titles; (2) it may wish to complete its holdings of the magazines which published a single writer, or those which represent a single tendency in modern literature or a single region. Whatever its wishes are, the student of modern literature probably will be grateful for such assistance. But, above all, the "indispensable minima" of im- portant magazines cannot be ignored in planning for research in modern literature.

One other suggestion should perhaps be made here, which may appear presumptuous in a nonlibrarian to discuss. Those who have worked with little magazines in this early, pioneering stage of their history have sometimes been handicapped in their work because there has been no separate classification of little magazines in library files. It would be of great value to both student and professor to refer to a separate catalog of little magazines in the library's files. It is of some assistance, but not much, to have these little magazines given a special designation, even though they are grouped with other magazines in the periodical card catalog. A separate shelflist or card file of them would of course be a tremendous help. Before such a file can be made, some adequate definition of the little magazine must be made as a guide in selecting the titles which belong in the file.

It is with the academic needs of the immediate future that this article is most concerned. Perhaps the groundwork for scholarship in twentieth-century letters needs yet to be laid, before competent study can be done with some measure of convenience. It is not too early for that preliminary work. In fact, it is a necessity to modern scholarship. Undoubtedly, the scholarly equipment needed for a reevaluation of twentieth-century literature will be provided in the early future. 